\title{
COMPARISON BETWEEN SOME MORPHO-ANATOMICAL FEATURES AT FOSSIL VEGETAL SPECIES AND AT THEIR ACTUAL CORRESPONDENT SPECIES
}

\author{
GABRIEL C. CORNEANU ${ }^{1}$, MIHAELA CORNEANU ${ }^{1}$ \& RODICA BERCU ${ }^{2}$
}

\begin{abstract}
The values of some morpho-anatomical features (the size and shape of the epidermic cells of the leaves, as well as the size and features of the stomata) recorded in some fossil vegetal species and their actual correspondent species were analysed. These differences offer information about the evolution process. In the case of the analysed species (Ginkgo sp., Taxus sp., Magnolia sp. and Buxus sempervirens), two hypotheses concerning the genetic mechanisms involved in evolution and in the speciation processes or in the adaptation to the environmental conditions can be considered. These genetic mechanisms are: the multiplication of genomes and the process of gene amplification. They both result in an increase in epidermic cells and stomata size, as well as in the enzymatic activity, which determines a better adaptation to the environmental conditions, as well as to the settlement of the speciation process.
\end{abstract}

Keywords: fossil and actual vegetal species; Miocene, Pliocene, morpho-anatomical features; genetic processes in evolution.

\section{INTRODUCTION}

In the studies of the evolution processes, the fossil forms and their connections with the actual ones have a great importance. Every species presents particular features, and during the evolution or the adaptation to the environmental conditions, different genetic mechanisms were involved (polyploidy degree, genic amplification, chromosomal reorganisation, etc.). Different authors pointed out that the size and shape of the epidermal cells or stomata cells, have importance in taxonomy. The research by Sanda (1972), Simeanu \& Corneanu (1978), Corneanu \& Simeanu (1980, 1990 ) etc. underlined that some features of the epidermal cells and the stomata type are important to the determination of the Dianthus species of the Romanian flora. Similarly, Corneanu \& Popescu (1991) recorded some differences among the Fritillaria species of the Romanian flora, regarding the shape and size of the epidermal cells of the leaves.

The analysis of the interspecific or intraspecific variability of the size of epidermic cells and stomata in different populations of some actual Crocus species recorded similar values of the stomata length in the $C$. flavus Vest populations with the same polyploidy degree, and different values in different populations of $C$. vernus (Linné) Hill with a different polyploidy degree (Corneanu et al., 2003).

\footnotetext{
${ }^{1}$ University of Craiova, Genetics Dept., A.I. Cuza 13, 200585-Craiova, Romania

2 "Ovidius" University of Constanța, Biology Dept., 900527-Constanța, Romania
} 
In this paper some features of the epidermic cells (the size of the epidermal cells, as well as the size and shape of the stomata), in the fossil forms and their actual correspondent species were analysed. This analysis allows detecting some genetic processes involved in the speciation process and/or adaptation to the environmental conditions.

\section{MATERIAL AND METHODS}

\section{Biological material}

Fossil species. The values of some morpho-anatomical indices (the size of the epidermal cells and stomata, as well as some morphological features or leaf morphology) of the fossil species from Miocene or Pliocene were used; these data were kindly provided by Prof. Dr. Răzvan Givulescu. The fossil species, their provenance and their references are the following:

Ginkgo adiantoides (UNGER, 1845) HEER, 1878, Upper Miocene, Chiuzbaia, Maramureş (Givulescu, 1990) or Upper Miocene, Pannonian, Tinca, Bihor (Givulescu, 1996)

Taxus inopinata GIVULESCU, 1973, Upper Miocene, Chiuzbaia, Maramureş (Givulescu, 1990, 1996).

Magnolia liblarense (KRÄSEL et WEYLAND, 1959) KVACEK, 1991, Miocene, Upper Pannonian, Delureni, Bihor (Givulescu, 1996, 2003).

Buxus sempervirens LINNÉ, 1753, Upper Miocene, Chiuzbaia, Maramureş (Givulescu, 1990, 2003).

Actual species. For actual species, the analysis was made on species corresponding to the fossil ones. The systematic position of the actual species, as well as the harvest sites are the following:

Phylum Spermatophyta, Subphylum Pinophytina (Gymnospermae), Class Ginkgopsida, Order Ginkgoales, Family Ginkgoaceae, Ginkgo biloba Linné 1771, Botanical Garden Craiova, $85 \mathrm{~m}$ alt.

Phylum Spermatophyta, Subphylum Pinophytina (Gymnospermae), Class Pinopsida (Coniferopsida), Order Taxales, Family Taxaceae, Taxus baccata Linné 1753, Botanical Garden Craiova, $85 \mathrm{~m}$ alt.

Phylum Spermatophyta, Subphylum Magnoliophytina (Angiospermae), Class Magnoliopsida, Subclass Magnoliidae, Order Magnoliales, Family Magnoliaceae, Magnolia kobus De Candolle 1818, Botanical Garden Craiova, $85 \mathrm{~m}$ alt.

Phylum Spermatophyta, Subphylum Magnoliophytina (Angiospermae), Class Magnoliopsida, Subclass Rosidae, Order Euphorbiales, Family Buxaceae, Buxus sempervirens Linné 1753, Botanical Garden Craiova, 85 m alt.

\section{Work method}

In actual species, 30 biometric observations on mature plants (at flowering) were made. The size and shape of the epidermic cells and the stomata length were recorded. For fossil species, the biometric values provided by the kindness of Prof. Dr. Răzvan Givulescu were used. The biometric values were statistically interpreted. 


\section{RESULTS AND DISCUSSIONS}

The speciation and evolution processes taking place in the geologic time can be explained through the analysis of the adaptation and speciation processes, which take place in the present. In this paper two mechanisms are exemplified: the polyploidy process and the gene amplification.

A. The polyploidy degree plays a role both in the speciation process and in the increase in the degree of adaptation to the action of certain stress factors. As a consequence of the genome multiplication, the polyploid forms present larger dimensions of the nucleus, as well as of the epidermal cells and stomata. So, because of the presence of each gene in a multiple number, the polyploid forms show a higher biosynthetic activity, having a higher degree of adaptation to environmental conditions. Thus, in the actual flora, Tephrocactus glomeratus (Haw.) Backbg. (Cactaceae family) is an octoploide species $(2 n=8 x=88)$ which vegetate at an altitude of $4000 \mathrm{~m}$ (Corneanu, 1984).

B. Gene amplification processes lead to an increase in the number of some genes, as well as in the DNA amount. Thus, Lazányi (1983) showed that in the case of cultivated wheat sorts, an increase in the DNA amount per cell, as well as an increase in the cell size, as a result of the gene amplification process, were noticed.

\section{Ginkgoales Family}

The species from the Ginkgoales order appeared in late Carboniferous early Permian. They greatly developed in Jurassic and suddenly declined in Cretaceous. At present they are represented by one genus with one species, Ginkgo biloba Linné 1771.

Ginkgo adiantoides (Unger 1845) Heer 1878, from Upper Miocene, Chiuzbaia, Maramureş, had the following dimensions: 48 (?) and $80 \mathrm{~mm}$ for the petiole length, $22 \mathrm{~mm}$ for leaf length, $40 \mathrm{~mm}$ for leaf width, L/l ratio of 0.55 (Givulescu, 1990). The leaf of Ginkgo adiantoides (Unger) Heer from Upper Miocene, had the lower epidermis made of cells in prolonged polygonal or rectangular shape, with straight or slightly curved walls. Small stomata, irregularly disposed, have a variable number of annexed cells (Givulescu, 1990).

The samples from Miocene, Pannonian from Tinca, Bihor, had the following dimensions of the cells from the lower epidermis: $70-98 \mu \mathrm{m}$ in length and $21 \mu \mathrm{m}$ in width, respectively [49] $63-70 \mu \mathrm{m}$ in length and $35 \mu \mathrm{m}$ in width, the stomata length of $21 \mu \mathrm{m}$ (Givulescu, written communication 1996).

In the actual correspondent species, Ginkgo biloba Linné, the following values were recorded: petiole length $15-110 \mathrm{~mm}$ (mean $51.60 \mathrm{~mm}$ ), leaf length 30 $80 \mathrm{~mm}$ (mean $45.94 \mathrm{~mm}$ ) and leaf width $55-135 \mathrm{~mm}$ (mean of $74.84 \mathrm{~mm}$ ). The upper epidermis is made of cells with thick walls, slightly sinuous, in quadrilateral shape (Fig. 3). The lower epidermis has rows of cells with stomata alternating with rows of cells without stomata (Fig. 4). On the rows of cells without stomata, the cells are prolonged, with straight walls and rectangular in shape. On the rows with stomata, the epidermal cells are usually polygonal in shape, with a slightly irregular outline. The cell length is relatively equal to their width. The small stomata are irregularly disposed. The microscopic structure of the actual species is similar to the structure of the fossil species (Givulescu, 1990). 
The size of epidermal cells and stomata is presented in Table 1. As to the epidermal cell size in the fossil species, the values of the cell size are distributed in the lower and middle part of the variability limits of the actual species. As to the stomata length, the values recorded in the actual species are higher than the values recorded in the fossil species. These differences can have different origins: the small number of observations in the fossil species or the result of a gene amplification process, which led to an increase in the nucleus and cell size.

Table 1.

The size of the epidermal cells and stomata in fossil and actual correspondent species

\begin{tabular}{|c|c|c|c|c|c|c|c|c|}
\hline \multirow{3}{*}{ Species } & \multicolumn{5}{|c|}{ Actual species } & \multicolumn{3}{|c|}{ Fossil species } \\
\hline & \multirow{2}{*}{\multicolumn{2}{|c|}{ Analysed feature }} & \multirow[t]{2}{*}{$\begin{array}{l}\text { Limits of } \\
\text { variability }\end{array}$} & \multirow{2}{*}{$\begin{array}{c}\text { Mean } \pm \\
\text { standard } \\
\text { deviation }\end{array}$} & \multirow[t]{2}{*}{$\mathrm{S} \%$} & \multirow[t]{2}{*}{ Species } & \multicolumn{2}{|c|}{$\begin{array}{c}\text { Mean or } \\
\text { Limits of variability }\end{array}$} \\
\hline & & & & & & & \multicolumn{2}{|c|}{ Miocene, Pannonian } \\
\hline \multirow{6}{*}{ 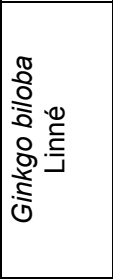 } & \multirow{2}{*}{\begin{tabular}{|c|} 
Upper \\
epidermis \\
\end{tabular}} & Cell length $(\mu \mathrm{m})$ & $41.3-137.6$ & $94.5 \pm 5.9$ & 34.7 & \multirow{6}{*}{ 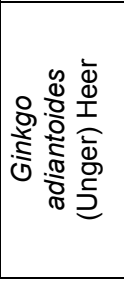 } & \multicolumn{2}{|c|}{$70-98$} \\
\hline & & Cell width $(\mu \mathrm{m})$ & $18.9-43.0$ & $30.2 \pm 1.1$ & 20.5 & & \multicolumn{2}{|c|}{21} \\
\hline & \multirow{4}{*}{$\begin{array}{c}\text { Lower } \\
\text { epidermis }\end{array}$} & Cell length $(\mu \mathrm{m})$ & $32.7-120.4$ & $66.1 \pm 3.6$ & 30.2 & & \multicolumn{2}{|c|}{$63-70[49]$} \\
\hline & & Cell width $(\mu \mathrm{m})$ & $15.5-31.0$ & $23.0 \pm 0.6$ & 16.6 & & \multicolumn{2}{|c|}{35} \\
\hline & & $\begin{array}{c}\text { Stomata } \\
\text { length }(\mu \mathrm{m})\end{array}$ & $44.7-55.0$ & $49.8 \pm 0.6$ & 6.4 & & \multicolumn{2}{|c|}{21} \\
\hline & & $\begin{array}{c}\text { Stomata } \\
\text { density/mm }{ }^{2}\end{array}$ & $66.7-155.6$ & $114.1 \pm 4.6$ & 22.1 & & \multicolumn{2}{|c|}{ * } \\
\hline & & & & & & & Miocene & Pliocene \\
\hline \multirow{6}{*}{ 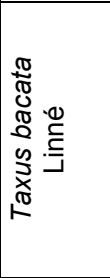 } & \multirow{2}{*}{\begin{tabular}{|c|} 
Upper \\
epidermis
\end{tabular}} & Cell length $(\mu \mathrm{m})$ & $27.5-82.5$ & $51.4 \pm 2.9$ & 30.4 & \multirow{6}{*}{ 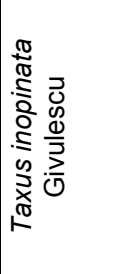 } & $32-64$ & $32-64$ \\
\hline & & Cell width $(\mu \mathrm{m})$ & $21.3-37.5$ & $28.5 \pm 0.8$ & 14.8 & & 22 & $23-27$ \\
\hline & \multirow{4}{*}{$\begin{array}{c}\text { Lower } \\
\text { epidermis }\end{array}$} & Cell length $(\mu \mathrm{m})$ & $55.0-107.5$ & $82.5 \pm 2.9$ & 19.5 & & * & * \\
\hline & & Cell width $(\mu \mathrm{m})$ & $17.5-30.0$ & $22.7 \pm 0.6$ & 15.4 & & * & * \\
\hline & & $\begin{array}{c}\text { Stomata } \\
\text { length }(\mu \mathrm{m})\end{array}$ & $32.5-40.0$ & $37.0 \pm 0.5$ & 7.4 & & 36 & 36 \\
\hline & & $\begin{array}{c}\text { Stomata } \\
\text { density } / \mathrm{mm}^{2}\end{array}$ & $\begin{array}{c}111.1- \\
177.8 \\
\end{array}$ & $148.9 \pm 6.7$ & 14.2 & & * & * \\
\hline & & & & & & & \multicolumn{2}{|c|}{ Miocene } \\
\hline \multirow{6}{*}{ 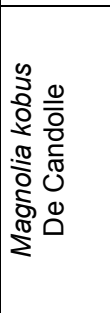 } & \multirow[t]{2}{*}{\begin{tabular}{|c|} 
Upper \\
epidermis
\end{tabular}} & Cell length $(\mu \mathrm{m})$ & $42.2-89.4$ & $62.6 \pm 1.6$ & 13.6 & \multirow{6}{*}{ 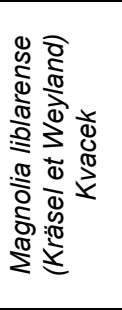 } & $\begin{array}{c}{[35] 42-} \\
56-63\end{array}$ & 27.5 \\
\hline & & Cell width $(\mu \mathrm{m})$ & $25.8-46.4$ & $34.6 \pm 0.8$ & 13.2 & & $21-28$ & 15 \\
\hline & \multirow{4}{*}{$\begin{array}{c}\text { Lower } \\
\text { epidermis }\end{array}$} & Cell length $(\mu \mathrm{m})$ & $25.3-71.3$ & $46.4 \pm 2.5$ & 29.9 & & * & 27.5 \\
\hline & & Cell width $(\mu \mathrm{m})$ & $11.5-25.3$ & $17.5 \pm 0.7$ & 21.3 & & * & 15 \\
\hline & & $\begin{array}{c}\text { Stomata } \\
\text { length }(\mu \mathrm{m})\end{array}$ & $23.0-27.6$ & $25.6 \pm 0.2$ & 5.1 & & $\begin{array}{c}28,35 \\
42\end{array}$ & $20-30$ \\
\hline & & $\begin{array}{c}\text { Stomata } \\
\text { density } / \mathrm{mm}^{2}\end{array}$ & $400-533.3$ & $\begin{array}{c}450.4 \pm \\
13.6 \\
\end{array}$ & 16.5 & & & \\
\hline & & & & & & & \multicolumn{2}{|c|}{ Miocene } \\
\hline & Upper & Cell length $(\mu \mathrm{m})$ & $17.5-35.0$ & $26.7 \pm 0.8$ & 16.2 & & & * \\
\hline & epidermis & Cell width $(\mu \mathrm{m})$ & $13.8-22.5$ & $18.3 \pm 0.5$ & 13.5 & & & * \\
\hline$\omega \stackrel{\bar{d}}{\triangleq} . \omega$ & & Cell length $(\mu \mathrm{m})$ & $20.0-36.3$ & $25.9 \pm 0.7$ & 15.2 & $\omega \stackrel{\widehat{\varrho}}{\varrho}$ & & t \\
\hline$\underset{x}{2} \stackrel{\oplus}{\subseteq}$ & Lower & Cell width $(\mu \mathrm{m})$ & $12.5-21.3$ & $17.1 \pm 0.4$ & 12.2 & $\underset{x}{x} \stackrel{0}{=}$ & & * \\
\hline 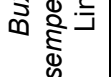 & epidermis & $\begin{array}{c}\text { Stomata } \\
\text { length }(\mu \mathrm{m})\end{array}$ & $30.0-40.0$ & $33.5 \pm 0.5$ & 8.2 & ติ & 27.3 & -40.7 \\
\hline & & $\begin{array}{c}\text { Stomata } \\
\text { density } / \mathrm{mm}^{2}\end{array}$ & $\begin{array}{c}155.6- \\
244.4\end{array}$ & $191.1 \pm 4.5$ & 12.8 & & & * \\
\hline
\end{tabular}

* No available data 


\section{Taxaceae Family}

The oldest group of the Pinopsida (Coniferopsida) class appeared in late Carboniferous. In this group, the speciation processes probably took place through mutagenesis, gene amplification or aneuploidy processes.

Taxus inopinata Givulescu 1973, Upper Miocene, Chiuzbaia, Maramureş, had the upper epidermis made of cells with straight and thick walls, quadrilateral or square in shape, with round edges. They are disposed in straight parallel rows. The lower epidermis had rows of cells with stomata alternating rows of cells without stomata (Fig. 1). On the rows without stomata, the cells were square in shape, with straight walls and round edges. On the rows with stomata, the cells were rectangular in shape (Givulescu, 1990). The stomata disposed in rows, unequally spaced out, having 4-5 annexed cells of variable shape (Fig. 1). On the lower epidermis the cells had $32-64 \mu \mathrm{m}$ in length and $32-64 \mu \mathrm{m}$ in width. The stomata length was of $22 \mu \mathrm{m}$ (Givulescu, 1990).

In an sample of Taxus inopinata Givulescu, Chiuzbaia, Maramures, the following values for the epidermal cells were recorded: $32-64 \mu \mathrm{m}$ in length, $23-27 \mu \mathrm{m}$ in width and $36 \mu \mathrm{m}$ in stomata length (Givulescu, written communication 1996).

The actual species, Taxus baccata Linné $1753(2 n=24$; Bolkovskikh et al., 1969; Guinea Lopez \& Ceballos Jimenez, 1974) has the upper epidermis made of quadrilateral cells with thick walls, disposed in rows (Fig. 5). The lower epidermis, made of rows of cells with stomata alternating with rows of cells without stomata (Fig. 6), has similar features to the species from Miocene. Within the variability limits for the size of the epidermal cells and the stomata length in the actual species, the values reported for the fossil species from Miocene are present (Table 1). These features underlined the affinity between the two species. The gene amplification processes can be involved in the adaptation and/or speciation processes.

\section{Magnoliaceae Family}

Angiospermae (Subphylum Magnoliophytina) appeared in late Jurassic, while the Magnoliaceae family has had representatives since Lower Cretaceous (Petrescu \& Dragastan, 1981). The Magnolia liblarense (Kräusel et Weyland 1959) Kvacek 1991 species originates in Miocene, Upper Pannonian, Delureni, Bihor (Givulescu, written communication 1996). The actual correspondent species are Magnolia salicifolia (Siebold et Zuccarini 1835, 1844) Maximovicz 1859 and M. dealbata Zuccarini 1844 (Givulescu, written communication 1996), which are not represented in the European Flora. In the fossil species, the epidermal cells had a length of [35] - $42-56-63 \mu \mathrm{m}$, and a width of 21 and $28 \mu \mathrm{m}$. The stomata were variable in length, with values of 28,35 and $42 \mu \mathrm{m}$ (Givulescu, written communication 1996). In another sample, for the upper epidermis, the following values were recorded: $27.5 \mu \mathrm{m}$ for the cell length, $15 \mu \mathrm{m}$ for the cell width, as well as 20 and $30 \mu \mathrm{m}$ for the stomata length (Givulescu, written communication 2003).

The biometric observations were made on the actual species, Magnolia kobus De Candolle $1818(2 n=2 x=38)$. The upper epidermis consists of cells with extremely sinuous walls (Fig. 7), with a length of $62.55 \mu \mathrm{m}$ (within the limits 48.2 $89.4 \mu \mathrm{m}$ ) and a width of $34.57 \mu \mathrm{m}$ (within the limits $25.8-46.4 \mu \mathrm{m}$ ). The lower epidermis consists of cells with slightly sinuous walls (Fig. 8), having a length of $46.38 \mu \mathrm{m}$ (within the limits $25.3-71.3 \mu \mathrm{m}$ ) and a width of $17.52 \mu \mathrm{m}$ (within the limits $11.5-25.3 \mu \mathrm{m})$. The regularly disposed stomata are $25.60 \mu \mathrm{m}$ in length (within the limits $23.0-27.6 \mu \mathrm{m}$ ). The biometric values recorded for the epidermal cell size in the fossil species Magnolia liblarense are distributed within the variability 
limits of the actual diploid species Magnolia kobus De Candolle (Table 1). As for the stomata size case, the values of the stomata length recorded for the fossil species are higher than the dimensions of the actual species (Table 1). This difference can have different sources: errors of measuring; the reduction of the stomata length in geological time, together with an increase in their density, etc. The actual species Magnolia kobus is not a species corresponding to Magnolia liblarernse from Miocene.

\section{Buxaceae Family}

The Buxus sempervirens Linné 1753 species, the fossil form from Upper Miocene, Chiuzbaia, Maramureş, has macroscopic and microscopic morphological features similar to those of the actual species Buxus sempervirens Linné 1753 (Givulescu, 1990). The sample from Miocene had both epidermises made of isodiametric polygonal or pentagonal cells, regularly disposed. This species was hypostomatic. A group of 7-8 radially disposed epidermal cells, having a semilunar shape, surrounded the stomata cells of the same shape (Fig. 2). Stomata are of $27.3-40.9 \mu \mathrm{m}$ in length (Givulescu, written communication 2003).

The actual species, Buxus sempervirens Linne $1753(2 \mathrm{n}=4 \mathrm{x}=28)$, has the upper epidermis made of polygonal cells usually with $5-6$ (rarely 4 ) sides, of a relatively equal size, with straight thick walls and round edges (Fig. 9). The length of the epidermal cells was of $22.66 \mu \mathrm{m}$ (within the limits $48.2-89.4 \mu \mathrm{m}$ ) and the width of $18.29 \mu \mathrm{m}$ (within the limits $13.75-22.50 \mu \mathrm{m}$ ).

The lower epidermis is made of polygonal cells with $5-6$ (rarely 4 ) sides, with straight walls and slightly higher in length than in width (Fig. 10). The epidermal cells are $25.88 \mu \mathrm{m}$ in length (within the limits $20.0-36.25 \mu \mathrm{m}$ ) and $17.08 \mu \mathrm{m}$ in width (within the limits $12.50-21.25 \mu \mathrm{m}$ ). Stomata are relatively regularly disposed, they are surrounded by 7-8 epidermal cells with concave walls adjacent to stomata cells. The stomata length was of $33.50 \mu \mathrm{m}$ (within the limits $30.0-40.0 \mu \mathrm{m}$ ).

The microscopic structure of the leaf from Miocene (Givulescu, 1990) is similar to the structure of the actual genotype. The stomata length is also variable within the variability limits of the actual species (Table 1). As the actual genotype is tetraploide and the fossil and actual species have the same structural features, the same size of the epidermal cells and the same stomata dimensions, the fossil species was probably tetraploid, too. This can be an example of a polyploid (tetraploid) species from geological time (Miocene).

\section{CONCLUSIONS}

A comparative study of some morpho-anatomical features of four fossil species (Ginkgo adiantoides (Unger 1845) Heer 1878, Taxus inopinata Givulescu 1973, Magnolia liblarense (Kräusel et Weyland 1959) Kvacek 1991 and Buxus sempervirens Linné 1753) and the correspondent actual species was made. This analysis allows supposing the existence of two genetic mechanisms involved in the speciation and evolution process, represented by the polyploidy phenomenon and gene amplification.

The biometrics values, as well as the microscopic features of the leaf structure, suggest that the actual tetraploid species Buxus sempervirens Linné, is similar to the fossil species Buxus sempervirens Linné from Miocene. In this case, the speciation through polyploidy took place in Miocene.

\section{Acknowledgements}

The authors express their sincere gratitude to Prof. Dr. Răzvan Givulescu, Cluj-Napoca, honorary member of the Romanian Academy, for the paleontological data he provided and for the permission to use some biometric values from his papers. 


\section{REFERENCES}

Bolkhovskikh, Z., Grif, V., Matvejeva, T. \& Zakharyeva, O., 1969, Chromosome numbers of flowering plants. Izd. Nauka, Leningrad.

Ciocârlan, V., 2000, Flora ilustrată a României. Pteridophyta et Spermatophyta. Edit. Ceres, Bucureşti.

Corneanu, C.G. \& Popescu G.G., 1981, Distributional and anatomical studies on Fritillaria (Liliaceae) in Romania. Willdenowia, 11, pp. 307-315, Berlin.

Corneanu, G., 1984, Genetica Cactaceelor. In: Cactuşii din România (Eds. S. Copăcescu, B. Bobîrnac, V. Grigoraş). Edit. Scrisul Românesc, Craiova.

Corneanu, C.G. \& Simeanu, V., 1980, Studiul citotaxonomic, morfologic şi anatomic al unor specii ale genului Dianthus. (Nota 2-a). Trav. Station "Stejarul", Ecologie Terrestre et Génétique, pp. 65-72, Pângărați.

Corneanu, C.G. \& Simeanu, V.D., 1990, Studii morfo-anatomice asupra unor specii ale genului Dianthus (Nota 3-a). Analele Universității Craiova, Biol.-Agron.-Hortic., XX (1989) + XXI (1990), pp. $65-68$, Craiova.

Corneanu, C.G., Corneanu, M., Niculescu, M. \& Răduțoiu, D., 2003, The intraspecific and interspecific variability in Crocus flavus and Crocus vernus species. Acta Horti Bot. Bucurestiensis, 30, pp. 61-70, Bucureşti.

Givulescu, R., 1990, Flora fosilă a miocenului superior de la Chiuzbaia. Edit. Academiei Române, Bucureşti.

Givulescu, R., 1996, written communication.

Givulescu, R., 1998, Flora fosilă a jurasicului inferior de la Anina. Edit. Academiei Române, Bucureşti.

Givulescu, R., 1999, Flora mică ilustrată a terțiarului din România. Casa Cărții de Ştiință, Cluj-Napoca.

Givulescu, R., 2003, written communication.

Guinea Lopez, J. \& Ceballos Jimenez, A., 1974, Elenco de la Flora Vascular Española (Peninsula y Baleares). Icona, Madrid.

Jacob, F., Jager, J.E. \& Ohmann, E., 1981, Kompendium der Botanik. VEB Gustav Fischer VIg., Jena.

Lazányi, E., 1983, Átöröklés és evolúció. Kriterion Könyvkiadó, Bukarest.

Petrescu, I. \& Dragastan, O., 1981, Plante fosile - introducere în paleobotanică. Edit. Dacia, Cluj-Napoca.

Sanda, V., 1972, Cercetări taxonomice în cadrul secției Carthusiani Boiss a genului Dianthus L. Studii şi Comunicări, Muzeul Brukenthal Sibiu, 17, pp. 147-157, Sibiu.

Simeanu, V. \& Corneanu, G., 1978, Studii morfo-anatomice asupra unor specii ale genului Dianthus (Nota 1). Analele Universității Craiova, Biol.-Agron.-Hortic., 9, pp. 19-26, Craiova.

Sitte, P., Ziegler, H., Ehrendorfer, F. \& Bresinsky, A., 1998, Strassburger - Lehrbuch der Botanick. 34. Auflage. Gustav Fischer, Stuttgart, Jena, Lübeck, Ulm.

\section{Plate I.}

\section{Explanations of the figures}

Fig. 1. Taxus inopinata Givulescu - Miocene. Lower epidermis with stomata (Givulescu, 1990).

Fig. 2. Buxus sempervirens L. - Miocene. Stomata (Givulescu, 1990).

Fig. 3. Ginkgo biloba L. - Actual. Upper epidermis.

Fig. 4. Ginkgo biloba L. - Actual. Lower epidermis.

Fig. 5. Taxus baccata L. - Actual. Upper epidermis.

Fig. 6. Taxus baccata L. - Actual. Lower epidermis.

Fig. 7. Magnolia kobus DC. - Actual. Upper epidermis.

Fig. 8. Magnolia kobus DC. - Actual. Lower epidermis.

Fig. 9. Buxus empervirens L. - Actual. Upper epidermis

Fig. 10. Buxus sempervirens L. - Actual. Lower epidermis. 

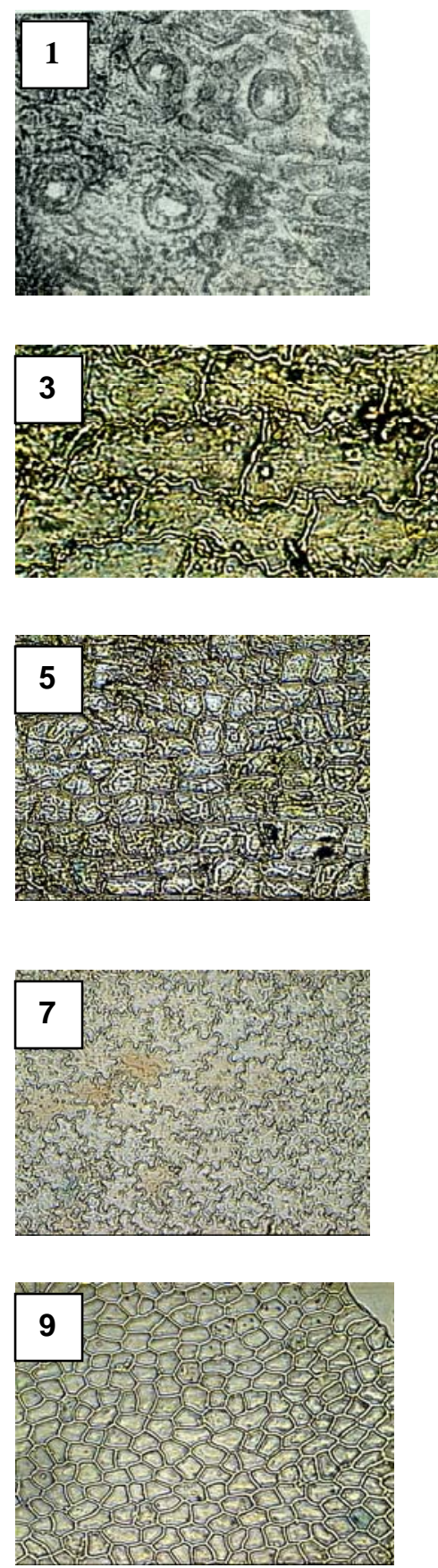
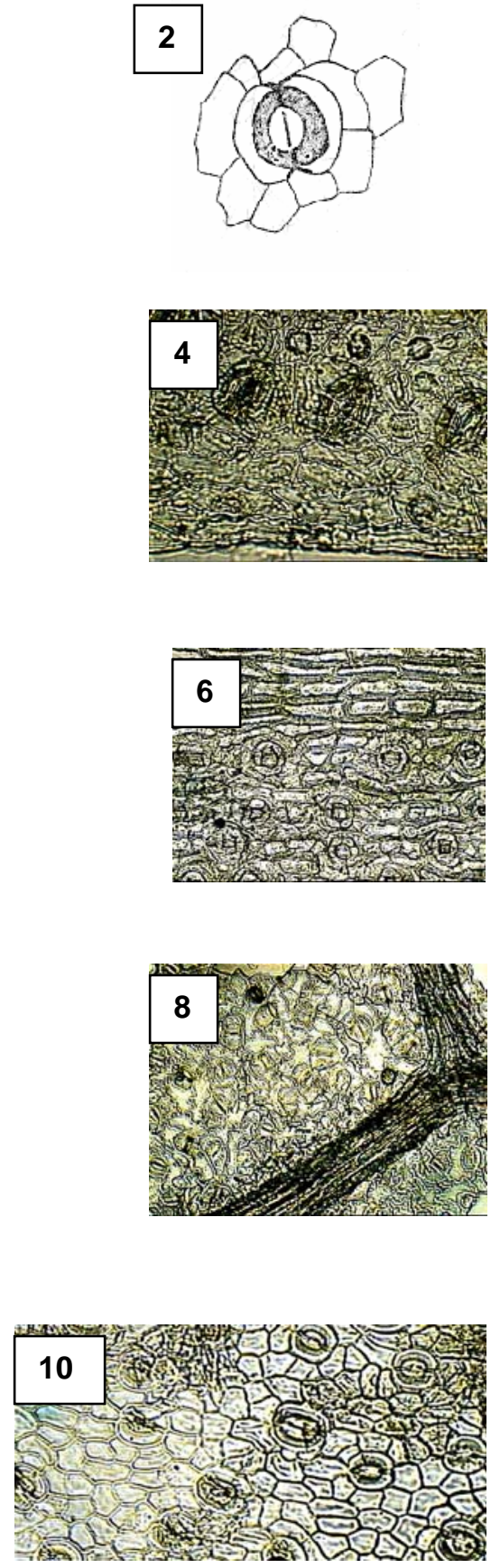